\title{
Gendered Pathways to the County-level People's Congress in China
}

\author{
Xinhui Jiang*
}

\begin{abstract}
Women are underrepresented in legislature almost worldwide, and China is no exception. Although the Chinese Communist Party (CCP) implemented its first gender quota in 1933, gender quotas and women's representation in China remain understudied. This study fills the literature gap by examining the subnational variation in gender quota implementation and women's representation in the county-level people's congresses (CPC). Through a comparison of four county-level units in Hunan and Hubei with similar socioeconomic features yet contrasting results in the numbers of female representatives elected in the 2016 CPC election, this study argues that women's access to CPCs is affected by the CCP's adoption and enforcement of grassroots quotas. The fieldwork shows that although all cases introduced a 30 per cent gender quota, only CPCs in Hunan province were able to meet the quota requirements. This was because the grassroots quota threshold was raised in Hunan and strictly enforced, partly as a response to the 2013 Hengyang vote-buying scandal. In contrast, CPCs in Hubei province nominated a large number of "first hands" (yibashou) candidates, very few of whom were women.
\end{abstract}

Keywords: women's representation; election in China; gender quota; gender and politics; people's congress

China's adoption of gender quotas in politics can be traced back to 1933 when the Chinese Communist Party (CCP) Controlled Border Region introduced a 25 per cent gender quota in its parliament. Yet, with a few exceptions, the implementation of gender quotas and women's representation in China's legislature remain understudied. ${ }^{1}$ According to some scholars, this omission is partly owing to the fact that descriptive representation in authoritarian regimes does not matter, since the legislature is not democratically elected. ${ }^{2}$ However, others have challenged this view and suggest that congresses in China, especially the popularly and competitively elected local ones, do offer substantive

* Institute of Chinese Studies, Freie Universität Berlin, Berlin, Germany. Email: Xinhui.Jiang@fu-berlin. de.

1 Among the exceptions are, e.g., Howell 2006; Wang, Qi 2015.

2 O’Brien 1990; 1994; Potter 1999; Sintomer and Zhou 2019. 
representation. ${ }^{3}$ For example, Melanie Manion's research on local congresses finds that members act as delegates for their constituencies and substantively represent them through the parochial provision of public goods. ${ }^{4}$ As such, this study addresses this literature gap by examining the subnational variation in the implementation of gender quotas and women's representation in China. Specifically, I compare women's representation in county-level people's congress (CPC) elections in the provinces of Hunan and Hubei in 2016.

This project uses the most similar method in case selection and draws on quantitative and qualitative data from four CPCs, as provincial-level differences are likely to manifest at the county level..$^{5}$ To maintain strong control of the crossprovincial comparison while also ensuring that the findings generalize more broadly, I selected one rural county and one urban district from each province. Each selected rural county or urban district resembles its counterpart in the other province in various socioeconomic metrics but differs drastically in the proportion of female representatives elected in the 2016 CPC election. Women make up 37 per cent of the total representatives in the Hunan rural county CPC; 13.8 per cent in the Hubei rural county CPC; 40 per cent in the Hunan urban district CPC; and 27 per cent in Hubei urban district CPC. Previous research explaining such variation suggests two theories. Scholars who follow a structural approach attribute women's underrepresentation to constraints including economic development or women's educational level. 6 Others apply a more nuanced and dynamic feminist institutionalism (FI) framework, which looks at factors including electoral institution, candidate nomination and gender norms' interference with both formal and informal institutions. ${ }^{7}$ While socioeconomic factors do matter, this study's selected county-level units resemble their counterparts across the two provinces in terms of economy, ethnic heterogeneity and women's average schooling. The examination of these paired counties' variations must therefore extend beyond structural conditions, centring instead on electoral rules and practices, which are heavily supervised and controlled by the CCP, according to previous studies. ${ }^{8}$ Thus, by examining how the CCP practises gatekeeping to (dis)enable women's inclusion, this study provides the first full account of subnational variation in quota enforcement and women's representation in China.

The article proceeds as follows. I first present the puzzle generated through fieldwork conducted in 2016 and 2017 in the four county-level units. I then detail the CPC selection/election process with specific attention to the gatekeeping practices of the CCP. Following that, I compare the positive cases in Hunan province with negative cases in Hubei province and show how Hunan's CPCs distinguished themselves and elected more women to the congress.

3 Manion 2015; Truex 2016; Huang and He 2018; Chang and Chao 2019.

4 Manion 2014; 2015.

5 Seawright and Gerring 2008.

6 Norris and Lovenduski 1995; Paxton and Kunovich 2003.

7 Krook and Mackay 2011; Kenny 2013; Barnes 2016.

8 Wang, Zhongyuan 2017. 


\section{Similar Counties, Different Results}

The cases were chosen to ensure sufficient variation on the dependent variable in the interest of disclosing one or more factors that differentiate the positive from negative cases. ${ }^{9}$ While the overall comparison is cross-provincial, I focus on a sample of representative county units within each province to ensure a close control of the comparison, which would not have been feasible if simply comparing all of the counties from one province to those of another. I first distinguish the urban districts ( $q u$ 区) from the rural counties (xian 县) within the two provinces so that the selected cases are drawn equally from each group. The reason for this distinction is twofold. First, both urban districts and rural counties are categorized at the second-lowest level in China's administrative hierarchy and employ direct and competitive elections for the CPC. ${ }^{10}$ Second, urban districts and rural counties differ in numerous ways but especially in terms of industrial structure and economic development. Selecting cases from both types of county-level unit enables the findings to be more broadly generalizable to the province level.

The next step is to ensure that each of the selected cases resembles its counterpart in the other province to control for factors that might affect women's representation. I first collected data from 107 rural counties and 92 urban districts within the two provinces. The selection strategy of "approximate matching" was then used, rather than exact matching, and thus involved arbitrary judgement of the closeness of cases. ${ }^{11}$ The compromise over exact matching is unavoidable, particularly considering the practical concerns of fieldwork access. Guided by eight independent variables and the proportion of women in the 2016 election, I selected ten similar units from each group across the two provinces based on their values across the independent variables (see Tables 1 and 2). Four of the 20 cases stood out for their unanimous adoption of a 30 per cent quota yet contrasting results in the 2016 election. To maintain the county units' anonymity, as requested by interviewees, I labelled these units as District A in Hunan, District B in Hubei, County A in Hunan, and County B in Hubei. As Table 1 shows, both District A in Hunan and District B in Hubei are among the most developed urban districts within the province, with a highly developed manufacturing and service economy and urbanization level (more than 99 per cent). The major difference between them is in the manufacturing sector and GDP, which can be explained by District A's recent acquisition of several industrial parks. Despite these points, their closeness - and hence comparability - in values across virtually all relevant covariates is notable, especially when considering the typical values and variability of these covariates for all cases in each sample (also depicted in Table 1 as reference points). Similarly, Table 2 indicates that both County A in Hunan and County B in Hubei are very similar and are also representative of the 107 rural counties with limited GDP and sizable grain products.

11 Gerring 2007, 135. 
Table 1: Urban District Cases

\begin{tabular}{|c|c|c|c|c|c|}
\hline & \multirow[b]{2}{*}{ District A } & \multirow[b]{2}{*}{ District B } & \multicolumn{3}{|c|}{ Mean } \\
\hline & & & All urban districts & Hunan districts & Hubei districts \\
\hline Population $(10,000)$ & 57 & 71 & $59.9(33.1)$ & $49.6(31.3)$ & $73.1(30.8)$ \\
\hline GDP (100 million) & 1429.7 & 762.9 & $344.8(257.9)$ & $326.8(293.2)$ & $367.1(207.3)$ \\
\hline Primary industry & 0.8 & 0.2 & $28.1(27.9)$ & $18.1(18.5)$ & $40.4(32.5)$ \\
\hline Secondary industry & 876.3 & 157.7 & $171.8(151.9)$ & $169.0(175.8)$ & $175.2(117.6)$ \\
\hline Tertiary industry & 552.6 & 605.0 & $146.3(163.5)$ & $139.7(157.2)$ & $154.5(172.6)$ \\
\hline Government revenue $(10,000)$ & 526433 & 577064 & $173880.2(164523.7)$ & $122769.5(128344.6)$ & $237456.9(183072.9)$ \\
\hline Government expenditure & 618961 & N/A & $278469.0(157387.8)$ & $242783.1(160475.0)$ & $345875.6(128918.8)$ \\
\hline Grain production (ton) & 67 & 0 & $537677.0(2523305.0)$ & $176254.5(193937.7)$ & $1079811.0(3955427.0)$ \\
\hline Proportion of women in 2016 election & $40 \%$ & $27 \%$ & N/A & N/A & N/A \\
\hline \multicolumn{6}{|c|}{$\begin{array}{l}\text { Source: } \\
\text { Hunan's data are from the } 2015 \text { Hunan Provincial Yearbook and Hubei's data are compiled from each prefecture's } 2015 \text { yearbook within Hubei province. } \\
\text { Notes: }\end{array}$} \\
\hline
\end{tabular}

Data are missing for 15 urban districts' registered population (huji renkou 户籍人口). I used the estimated number
population and registered population of other urban districts. The standard deviation is in parentheses. N=92. 

Moreover, both counties are enlisted in the national poverty reduction programme, with per capita income of less than 2,300 yuan (\$347) for farmers, ${ }^{12}$ and are located in mountainous regions which have only recently gained access to railways. The similarity of the selected cases allows for the various factors that might influence the proportion of female representation to be held constant.

In addition to their similarities, the selected cases are, to a large extent, representative of other county units within each province, and so the findings generated from the comparisons are generalizable to the broader set of county units within each province. Both County A and B are typical of the rural counties in their province in terms of demography, industry structure (for example, the presence of a large agricultural sector) and fiscal capacity, based on their closeness to the provincial mean across these relevant variables. The only exception is that both are less developed than the provincial average in terms of GDP. While the urban district cases may be relatively less representative of all other districts in their province, they more directly capture the core economies, population centres and urbanized districts within each province, especially those in and around each province's capital city. Districts A and B therefore represent typical urban areas in each province in terms of industry structure (for example, large manufacturing and service sectors) and strong government revenue. The inclusion of comparisons between two typical rural counties and between two advanced urban districts ensures obtaining the best of both worlds and thus more reliable conclusions.

While the pairs of cases have similar demographic, political and economic features, they show contrasting levels of women's representation. To examine this variation and explore how the CPC election rules affect women's access, this article draws on data gathered during two field trips conducted in autumn 2016 and summer 2017, covering the period during and after the 2016 CPC election. During these field trips, I conducted semi-structured interviews with 55 representatives (31 female and 24 male) and 18 electoral officials ( 9 female and 9 male) working at the electoral district (xuanqu 选区), township and county levels. In addition, I also collected biographical information on the members of the four CPCs, which was published in pamphlets and kept only for CPC members. These data included representatives' names, gender, occupation, party affiliation and educational background, and allowed me to analyse and compare the composition of the CPCs.

\section{The Party and the CPC Election}

China introduced direct and competitive elections for the CPC via the 1979 Electoral Law, which stipulates that "urban district, city that is not divided into districts, county, autonomous county, and township congress representatives

12 The poverty line of 2,300 yuan was used in 2016 in both counties. It has been raised since Xi launched the targeted poverty alleviation initiative. 
are directly elected by voters" (Article 2), and that "the number of candidates should range from half to one times more than the number of seats" (Article 27). According to the Electoral Law, the electoral process should comprise three stages: nomination, vetting (yunniang 酝酿) for the candidate shortlist, and voting. Although in theory the election is an open process during which voters can make nominations and vote freely, both Manion and Zhongyuan Wang note that the CCP has various informal rules to "keep election results on track with the Party's will." 13 Not only must the Party be seen to observe the Electoral Law and encourage voters' participation, it must also safeguard its chances of securing its desired outcome in the election by creating advantages for its preferred candidates. Some common tactics to this end include reserving seats for leading officials, mobilizing voters to nominate Party-approved nominees (what Manion calls pseudo voter nominees ${ }^{14}$ ), and deliberately looking for an unlikely candidate ( peipao houxuanren 陪跑候选人) who will fare poorly against the Party's preferred candidate. ${ }^{15}$

In the first stage, nominations may be made either by political parties and mass organizations, or by a group of ten or more registered voters. Following Manion's terminology, this study refers to nomination by parties and mass organizations as "Party nomination," since the nomination is under the CCP's supervision. ${ }^{16}$ The two types of nominees (Party nominees and voter nominees) then follow different nomination pathways to reach the candidate shortlist (See Figure 1). To ensure that the Party nominees are electable, they must first pass through a more complex and lengthy nomination process than that for voter nominees. Although Party nominees only constitute around 20 per cent of the total nominees, the likelihood of them being elected far surpasses that of the voter nominees being elected - Party nominees sometimes have a success rate of 100 per cent. ${ }^{17}$ The advantages given to Party nominees during the nomination and vetting process means that it is crucial for women to be nominated by the CCP first in order to stand any chance of winning the election.

\section{Candidate pools for Party nomination}

Party nomination relies on a wide array of agents and strong institutional support. While voter nomination only lasts around five days, Party nomination starts a month or two before the election day to allow for enough time to give the Party nominees a thorough preliminary vetting and ensure that they are competent. ${ }^{18}$ Agents for Party nominees include the county Party committee, the United

13 Wang, Zhongyuan 2017, 871; Manion 2008; 2015.

14 Manion 2015.

15 Wang, Zhongyuan 2017.

16 Manion 2015.

17 Liu, Zhi, et al. 2001.

18 According to the Electoral Law, voter registration (xuanmin dengji) should be completed 20 days before the election, and the local electoral authorities must publicize the list of nominees at least 15 days before the election, which leaves five days for voter nomination. 
Figure 1: Voter and Party Candidate Selection Process

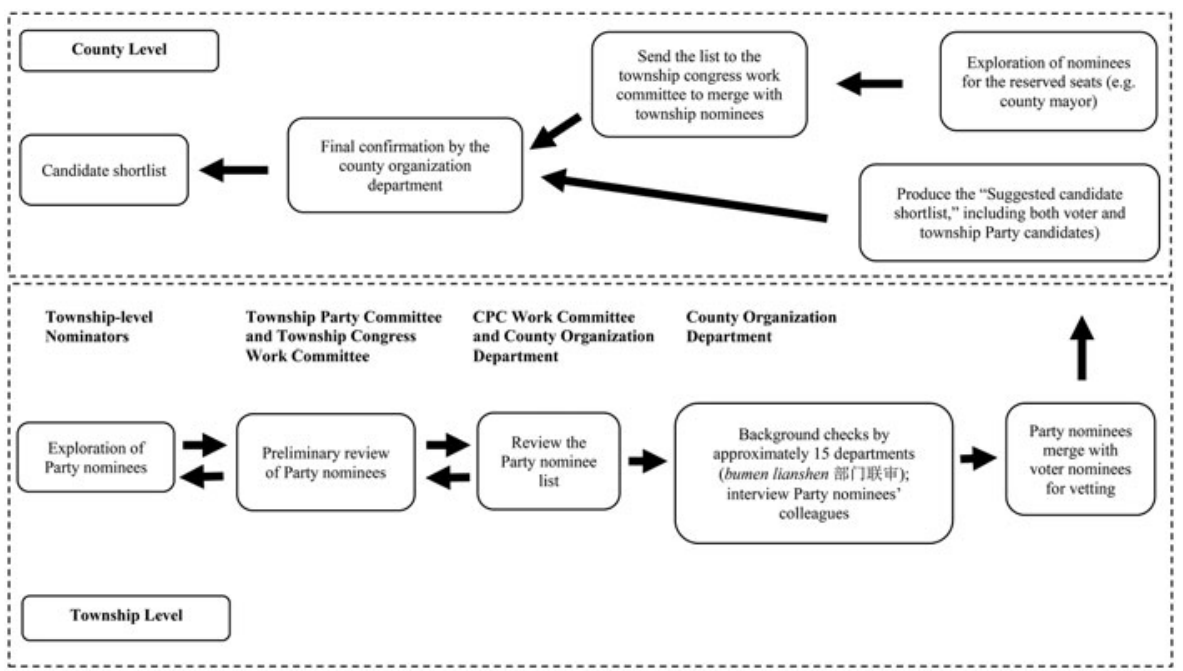

Front Work Department (UFWD), county-level bureaus and township-level agents. ${ }^{19}$ The township-level agents are from village/residential committees and major work units (for example, public schools and hospitals) within the jurisdiction. These agents make nominations through both functional and jurisdictional pools. For example, while the county Party committee nominates leading political figures such as the county mayor, the UFWD explores potential social elites outside of the public sector, including entrepreneurs and artists. ${ }^{20}$ County bureaus, village/residential committees and major work units then make withinjurisdiction nominations from within the bureau or village/neighbourhood.

The number of women in these pools greatly affects their chances and the nomination mechanisms. A lack of women in positions of political authority means that they are less likely to be nominated by the county-level Party committee exceptions include feminized positions such as the chairperson of the Women's Federation. On the other hand, it is far more likely for women to be nominated in units where women are in the majority, such as high schools or residential committees. Even though the nomination mechanisms vary across nominators, most of them are exclusive, non-transparent and centralized. ${ }^{21}$ Thus, many female

19 The CPC election is organized through the coordination of electoral institutions (e.g. election office and election committee) across three levels: county, township and electoral district. An election office is set up temporarily during the election in each electoral district and is the dispatched agency (paichu jigou) of the election committee. Election committees only exist at and above the township level and maintain a hierarchical relationship with the election offices within their jurisdiction. Both the election offices and election committees come under the administration of the CPC.

20 Wang, Xiong 2017.

21 For example, nomination at the village/neighbourhood level usually involves the committee members, occasionally with a few villagers/residents as voter representatives. In some major work units, the Party committee of the unit will convene a meeting for deliberation with a few Party members. 
nominees, especially those not in leadership positions, were unaware of their nomination before the release of the shortlist:

I work for a large work unit and it is a tradition for us to have a representative standing for this electoral district. This has been going on for decades. Frankly, I do not know why they [the Party committee of the work unit] picked me. Maybe they think I am reliable and responsible. $^{22}$

One day, the school principal asked me to send a file to the CPC. When I got there, the officials asked several random questions like, "how is your work?" I did not realize it was an interview until several days later when my supervisor told me I had been nominated as a candidate together with the school principal. ${ }^{23}$

\section{CCP intervention in nomination and vetting}

In addition to its appointment of nominators, the CCP further extends its control over CPC elections by imposing quotas and vetoing nominations before the vetting stage. While quotas are designed for the representativeness of the CPC, they are also a manifestation of the Party's will (zuzhi yitu 组织意图). Despite variations, most CPCs adopt quotas to guarantee the election of underrepresented groups, including farmers, workers, women, ethnic minorities and non-CCP members. Some also introduce quotas to limit the overcrowding of certain groups such as entrepreneurs or government officials. To illustrate with an example, County A in Hunan requires that:

The percentage of workers, farmers and professionals should surpass the last term; the percentage of women should be more than 30 per cent; incumbents should take no less than one-third of the total seats; the number of ethnic minorities and returned overseas individuals should be guaranteed based on the law; non-CCP members should make up no less than 35 per cent of the total; the number of government officials should not go beyond the last term. ${ }^{24}$

Electoral authorities' strategic implementation of quotas can work in the Party nominees' favour. To enforce quotas, the CPCs usually disaggregate quota requirements and allocate them to the township level before the nomination. Electoral authorities then purposefully use quotas to inform the Party nomination within its jurisdiction so that the Party nominees win easily against the voter nominees at the vetting stage, as they fit the CPC quota requirement. A staff member within District A summarized the process:

The quotas in the election work plan are designed for the whole county. But they [the voters] cannot see the big picture. Voters would not think of the quota when they nominate someone. So, when we get the nominee lists from all electoral districts of this town, it is our job to come up with a list that meets every quota requirement. ${ }^{25}$

The county organization department has the authority to adjust the Party nominee list before it goes public and reaches the vetting stage. For example,

22 Interview with Respondent HNYH015, District A, 13 June 2017.

23 Interview with Respondent HBJA006, District B, 28 June 2017.

24 Requested in person, County A, 31 July 2017.

25 Interview with Respondent HNGOV010, District A, 6 June 2017. 
the organization department and the CPC often veto nominations that fail to meet quota requirements in the early stage of nomination. In such cases, the township electoral authorities direct the agents in the electoral district to consider a more qualified nominee. As the same staff member recounted:

Sometimes, they [organization department] are not happy about the list we give them, and they return it. We then need to start all over again, you know, contacting the electoral district and asking for more names. I still remember that I was always on the phone with either the organization department or the election office, until midnight. ${ }^{26}$

The CCP also uses quotas to justify and push for its nominations during the vetting stage. Vetting for the candidate shortlist typically involves limited public participation (around ten citizens). The lack of public participation and the vagueness of candidates' qualifications provide a window of opportunity for CCP manipulation. Since it is extremely challenging, if not impossible, to select a pool of voter nominees who meet all intersectional quota requirements within the short time frame allowed, Party nominees often turn out to be the best options. For example, Sun Long describes how several Party committee members reminded the participants during the vetting of the importance of meeting the quotas assigned to the electoral district: the four shortlisted candidates had to include two ethnic minorities, two non-CCP members, one under 35 years old, one woman, and two grassroots representatives. ${ }^{27}$

\section{Gendered Impacts of CPC Election Rules}

This section uses the four selected cases to examine how CPC election rules impact women's chances of advancing to the shortlist. While all CPCs must follow the provincial election guidelines, which are released by the provincial people's congress before the election, they also have the discretion to adjust them and draft a local election plan, creating variations among CPCs within the same province. Included in the election plan are details such as electoral district delineation, the number of reserved seats, distribution of seats and quota assignments. The two positive cases (District A and County A in Hunan) differ in their election plans and enforcement of these plans from the negative ones (District B and County B in Hubei) primarily in their quota requirements and the top-down enforcement of quotas. Specifically, while all four cases adopted the same 30 per cent gender quota, County A and District A in Hunan had larger grassroots quotas and enforced them more strictly than did their counterpart county units in Hubei province, which favoured government officials and entrepreneurs, especially those who are the so-called "first hands" (yibashou 一把手), that is, the head of a unit. By safeguarding more 
grassroots candidates over first-hands, the CPCs of County A and District A enhanced women's participation.

\section{Grassroots, official and gender quotas}

Women's inclusion relies more on grassroots and government official quotas than on gender quotas, as gender quotas are more difficult to implement by design. Both grassroots and official representatives are defined as such according to their occupation and rank in the cadre system. Grassroots representatives can include workers, farmers and teachers, who together are labelled as frontline representatives (yixian daibiao 一线代表) by local electoral authorities. ${ }^{28}$ Notably, even though some grassroots representatives also work for the government, they are the rank and file and thus are classified as grassroots rather than officials. Government official representatives, on the other hand, include not only leaders such as the county mayor or bureau head but also village/residential committee directors and Party secretaries, as they are on the CCP's payroll and are customarily treated as officials in the jurisdiction by constituents.

The intersectional structure of quotas, combined with the way the CCP makes nominations, means that it is more difficult to implement gender quotas than to implement grassroots and government official quotas. Quotas are intersectional in the sense that there is no independent pool for quotas during nomination, and a candidate is allowed to double or triple dip several quotas. For example, a female county mayor would be covered by both gender and official quotas. Even though there is no independent pool for grassroots or official quotas, Party nomination is by and large conducted through occupational pools - village committees nominate farmers, public schools nominate teachers, hospitals nominate doctors, and the county Communist Party committee nominates officials. Accordingly, grassroots and official quotas are by design easier to implement. However, as there is no independent female candidate pool and because gender crosscuts occupations, the implementation of the gender quota is often secondary - the CPC only counts the number of women aggregately after it has received the candidate lists from all townships. While in theory the township electoral authorities should guarantee that there are a certain number of women among Party nominees, they frequently dismiss the gender quota requirement. ${ }^{29}$ A township official explained why they did not select enough women: "other townships might have more women than the quota requires. The CPC would take care of it when they have all the names." ${ }^{30}$ But if in reality the CPC and

28 Grassroots representatives' occupations vary from case to case. In certain cases, such as County B and District B, grassroots representatives also include technicians (zhuanye jishu renyuan). The consensus is that grassroots representatives should not be in any position of power, regardless of their occupation.

29 Liu, Zhi, et al. 2001; Zhang 2012.

30 Interview with Respondent HNGOV012, District A, 6 June 2017. 
township electoral authorities fail to coordinate well, it might be too late to remove some of the male candidates.

\section{Grassroots quotas for the 2016 elections in Hunan and Hubei}

Despite the difficulty of implementing gender quotas, County A and District A in Hunan brought in far more women than did their counterparts in Hubei province for two reasons. First, there is a larger share of women in grassroots representatives' nomination pools almost nationwide. Second, Hunan province set out to improve the representation of grassroots representatives following a vote-buying scandal in a previous election. For instance, in 2016, 97 per cent and 63 per cent of the kindergarten and primary school teachers in China were women. ${ }^{31}$ Similarly, most village committee family planning cadres are women, as women on the committee are trained for this position owing to their assumed natural connection with childbirth. Meanwhile, women are far less represented in the pool of government officials. ${ }^{32}$ In 2015, 38 per cent of counties in Hunan had no females in any leading positions in government bureaus. ${ }^{33}$ And, in those counties and prefectures that did have female leaders, the majority of the positions tended to be deputy positions. In the same year, women only accounted for 6.4 per cent and 7.18 per cent of department heads at the prefectural and county levels in Hunan. ${ }^{34}$ Similarly, only 3.41 per cent of the village committee directors in Hubei, 4 per cent of the village committee directors, and 5.1 per cent of the Party secretaries in Hunan were women. ${ }^{35}$ It is expected that including more grassroots representatives would give women a greater chance to make the list, and vice versa.

Despite the equally poor representation of women in leadership positions compared with Hubei, Hunan province distinguished itself in the 2016 election by directing its CPCs to raise the grassroots quota threshold. This decision to bring in more grassroots representatives was spurred by the Hengyang 衡阳 votebuying scandal, which occurred in 2012 and was investigated in 2013. According to China's Electoral Law, congresses at and above the prefectural level are elected by representatives one level down. Hengyang scheduled the election of its provincial people's congress representatives during the first session of the 14th prefectural people's congress in 2012. To secure their votes, 56 out of the 93 provincial congress candidates paid approximately a total of US\$17 million in bribes to 518 out of 527 prefectural representatives attending this meeting and also to 68 staff members working for the congress. ${ }^{36}$ Unsurprisingly, they

31 Liu, Tianhong 2017.

32 Su 2006; Wang, Zhengxu, and Dai 2013.

33 Hunan Provincial Bureau of Statistics 2016.

34 Ibid.

35 Liu, Shunni, and Ma 2016; "Hunan sheng chuangxin nongcun funü canzheng gongzuo jizhi” (Hunan's innovation for women's participation in rural governance). Zhongguo funü bao, 10 May 2016, http:/l www.women.org.cn/art/2016/5/10/art_22_146688.html. Accessed 27 April 2020.

36 Luo 2013. 
won 56 of the 76 seats. Most of the 56 representatives were local officials and entrepreneurs and included, among others, 32 entrepreneurs, 4 state-owned enterprise CEOs and 12 officials including county mayors and Party secretaries. ${ }^{37}$ The large number of representatives convicted of paying and taking bribes, and the sums involved, soon drew the attention of the Central Discipline Inspection Commission, which ordered the Hunan Provincial Discipline Inspection Commission to investigate. The investigation eventually led to the disqualification of the 56 provincial representatives, dismissal of the 512 prefectural representatives, ${ }^{38}$ and expulsion of several Party officials and electoral staff members in Hengyang.

Apart from the reshuffle of the Hengyang government, a less noticeable but equally important repercussion from this scandal was the CCP's refocus on the composition of the people's congresses. According to an official from Hunan Provincial Discipline Inspection Commission, the investigation revealed that a major factor behind the scandal was the "structural imbalance of the congress and the lack of background checks." 39 As noted above, there was not one single grassroots representative among the 56 representatives and even the three teacher representatives were school heads - the first hands of the institution. The push for stricter implementation of electoral rules in Hunan was reinforced during the 2016 National People's Congress meeting, when Xi Jinping visited the Hunan representatives and reminded them to follow the rules in the upcoming 2016 CPC election. ${ }^{40}$ As a result, Hunan decided to elect more grassroots representatives and reduce the share of officials and entrepreneurs, who are more privileged and better positioned to offer and take bribes, in the election following the Hengyang scandal. To this end, Hunan's provincial Party committee issued its "Opinion on strengthening and correcting the people's congress and political consultative conference representatives' work" (Guanyu jiaqiang he gaijin renda daibiao, zhengxie weiyuan youguan gongzuo shishi yijian 关于加强和改进人大代 表、政协委员有关工作实施意见) before the election. This document listed 15 problems with the past elections, one of which was the overrepresentation of officials and entrepreneurs, the majority of whom are male. The provincial Party committee then convened 13 meetings within a short period of time prior to the election to emphasize the importance of strictly implementing grassroots quotas and thoroughly vetting candidates, especially their financial backgrounds and the authenticity of their grassroots identity. In contrast, Hubei merely added the stipulation that the numbers of "grassroots workers, farmers, and technicians should surpass the last term's numbers" to its provincial election guidelines.

The changes to provincial-level guidelines soon manifested in the CPCs' election plans. Although the Hunan and Hubei provincial-level authorities were

38 Six of the representatives moved to another jurisdiction before the outcome of the investigation.

39 Tan 2016.

40 Wang, Shu 2016. 
following different approaches, CPCs could adjust the provincial election guidelines to suit local conditions. Consequently, within-provincial variations, although mostly modest, were inevitable. In addition, many CPCs adopted unquantifiable quotas, making it more challenging to conduct a systematic crossprovincial comparison. However, CPCs in Hunan still seemed to be more determined to restructure the congress. Many CPCs in Hunan (for example, Ningxiang 宁乡 and Taojiang 桃江), including District A, imposed a high grassroots quota threshold of 55 per cent. CPCs in Hubei, on the other hand, probably influenced by the non-commital wording at the provincial level, opted for some unquantifiable grassroots quota, including District B's the number of "grassroots workers, farmers, and technicians should surpass the last term," and County B's "the percentage of grassroots representatives should increase." For government official quotas, District A imposed a 22 per cent cap, and County A decided this term should have fewer official representatives than the last. Many county units in Hubei (for example, Tianmen 天门 and Chibi 赤壁), including both District B and County B, had a 25 per cent limit for officials. Even though the gap seemed small, many CPCs in Hunan included the sentence, "strictly control (congyan kongzhi 从严控制) the proportion of official representatives," in addition to the quota requirement. Some even specifically stipulated that the CPCs should not nominate any county-level bureau heads (Ningxiang county); others restricted the number of leaders from the county Party committee and the government to a maximum of five (Taojiang county).

\section{Quota implementation variations in Hunan and Hubei}

Not only did Hunan province guide the CPCs to adopt a higher grassroots quota threshold it also worked hard to guarantee its strict enforcement. The county organization department's veto power during the Party nomination stage allowed the two selected cases in Hunan to reject a handful of unqualified nominees when electoral authorities failed to implement grassroots quotas. A staff member working in the election logistics office for District A in Hunan recounted:

One public school first nominated their headmaster [a man]. But the CPC told us this is not going to work this time. They said they want a "real teacher" [most likely a woman]. So, we told the school to nominate a "real teacher." 41

The same thing happened in another electoral district. The representative attributed her nomination to the electoral authorities' preference for grassroots representatives over first hands:

The school leader told me that the election office required them to select a "grassroots" teacher instead of the headmaster (the first hand). And they also demanded a non-CCP member. I think that is why they nominated me..$^{42}$

41 Interview, Respondent HNGOV010.

42 Interview with Respondent HNYH004, District A, 7 June 2017. 
County A and District A also conducted thorough background checks of the nominees to confirm the authenticity of their grassroots identity. These checks were coordinated by multiple bureaus including the tax bureau and public security department. Almost all interviewees from Hunan, including some two- or three-term incumbents, mentioned that the 2016 election earned the reputation of being unprecedentedly strict (shishang zuiyan 史上最严). Many claimed that there were over 15 bureaus participating in the background checks. A Party nominee from District A recalled that the CPC even dug out an expired insurance policy she had bought for her daughter six years previously and questioned her "grassroots" identity for not reporting it in the first place. ${ }^{43}$

In the two cases in Hubei, however, CPCs refused to implement grassroots quotas and nominated first-hands candidates instead. It has long been the norm to nominate first hands for CPC elections in China, partly owing to the way the Party makes nominations. When agents select Party nominees, they do so in a centralized and exclusive way within a unit such as a bureau or a village. Often, the participants in those nomination meetings select the head of the unit as the default choice, simply because of the hierarchy of authority. For example, a female representative recounted that her nomination had taken her by surprise:

We had a meeting with all comrades above managerial positions. At first, we unanimously agreed to select our first hand because for many years it had always been him. But then he [the first hand] said he wanted me to do it because I am young and need some practice. That is how we made the decision. ${ }^{44}$

Similarly, in villages where the nomination meetings are only open to village committee members and a few villagers, the director or Party secretary usually wins the nomination:

In the village, it is usually either the Party secretary or the director of the village committee. Sometimes, the Party secretary has probably already been selected to be the Party congress representative. Then, it is the director. ${ }^{45}$

Although this was also the usual practice for Hunan CPCs, as mentioned above, Hunan implemented a policy to strictly enforce grassroots quotas and restrict nominations of first hands. In contrast, not only did County B and District B in Hubei nominate first hands from government agencies or private companies, they recategorized or relabelled these government officials and entrepreneurs (first hands in a company) as grassroots candidates in order to pay lip service to grassroots quotas. For example, in County B, the head of the county agricultural bureau was classified as a farming professional to meet the grassroots quota as he had some agricultural credentials. In addition, all village committee directors/Party secretaries in County B were classified as farmers - because they lived in the countryside. As there were no steps taken at the provincial level against such practices, the two CPCs did not bother to verify if candidates 
qualified under the correct quota categories; Hunan, on the other hand, carried out thorough checks. As a result, in County B, village committee directors and Party secretaries took 41.1 per cent of the seats, but because they had been categorized as farmers, they were deemed to be grassroots representatives. The electoral authorities' slack enforcement of quotas in Hubei was confirmed by representatives during interviews; no interviewee was able to recall any policy about the increase of grassroots representatives or provincial supervision of the enforcement of grassroots quotas. Although candidates had to watch a documentary about the Hengyang scandal, entitled Mirror (Jingjian 镜鉴), during the vetting stage, the two CPCs did very little else to ensure correct procedures were in force. As such, District B and County B in Hubei were able to elect government officials and entrepreneurs while appearing to meet their grassroots quotas.

In sum, although all cases from the two provinces had the same gender quotas for their CPCs, it was Hunan's resolve to increase the share of grassroots representatives and ensure the strict implementation of grassroots quotas that gave women better chances to be nominated and elected, as women tend to be better represented in the grassroots candidate pool. District B and County B, on the other hand, did exactly the opposite: they nominated from pools of government officials and entrepreneurs, under the norm of selecting first hands, where women tend to be less represented.

\section{Gendered structure of the selected CPCs}

This study shows that it is the increase of grassroots quota thresholds and the topdown enforcement of such quotas following the 2013 Hengyang scandal that have brought more women into CPCs in Hunan province. The effect of grassroots quotas on improving women's representation depends on two conditions. First, grassroots quotas should be higher, or at least equal to, the officials quota. Second, electoral authorities need to strictly police the implementation of grassroots quotas to prevent officials or entrepreneurs (both are typical first hands) from being nominated under the guise of grassroots representatives.

This finding is further supported by the analysis of the biographic data on the representatives from the four CPCs. To demonstrate that counties strictly enforcing grassroots quotas also have more women in their CPCs, I first used a dummy variable and coded every representative's occupation as "first hand" if the representative is the head of a unit, regardless of its administrative level and size. For example, even though the village committee is a grassroots-level administrative unit, the director and Party secretary of the committee are considered as the first hands of the village. I then included all types of first hands from both private and public sectors, including school headmaster, bureau head and president of private companies. Next, I ran a Chi-square test based on gender across four cases and the result supported the existence of the gender disparity between the group of grassroots and first-hands representatives. Based on a sample of 920 representatives, the chances of them holding a first-hand position before being 
Table 3: Composition of First Hands and Grassroots Representatives across Gender and Counties

\begin{tabular}{lcll}
\hline & First Hands & Grassroots & $\begin{array}{l}\text { Chi-square Tests of Independence } \\
X^{2}(1)=126.83, \mathrm{p}<0.001\end{array}$ \\
$\begin{array}{l}\text { Gender } n(\%) \\
\text { Male }\end{array}$ & $598(91.72)$ & $54(8.28)$ & \\
$\begin{array}{l}\text { Female } \\
\text { Urban district } n(\%)\end{array}$ & $163(60.83)$ & $105(39.18)$ & $X^{2}(1)=22.89, \mathrm{p}<0.001$ \\
$\begin{array}{l}\text { District A in Hunan } \\
\text { District B in Hubei }\end{array}$ & $168(78.14)$ & $47(21.86)$ & \\
$\begin{array}{l}\text { County } n(\%) \\
\text { County A in Hunan }\end{array}$ & $156(63.33)$ & $17(6.67)$ & $X^{2}(1)=26.52, \mathrm{p}<0.001$ \\
$\begin{array}{l}\text { County B in Hubei } \\
\text { Notes: }\end{array}$ & $199(88.84)$ & $25(11.16)$ & \\
$\quad$ & &
\end{tabular}

elected significantly differ by gender, $X^{2}(1, \mathrm{~N}=920)=126.83, \mathrm{p}<0.001$ (see Table 3). Similarly, each CPC case is significantly different from its counterpart in terms of the demographic structure of its grassroots and first-hands representatives. As expected, building on the Hunan cases' strong incentives to safeguard the inclusion of grassroots representatives and the Hubei cases continuing to select first hands, District A in Hunan and District B in Hubei, and County A in Hunan and County B in Hubei show significantly different patterns in their grassroots/first hands ratios: for urban districts, $X^{2}(1, \mathrm{~N}=470)=22.89, \mathrm{p}<$ 0.001; and for rural counties, $X^{2}(1, \mathrm{~N}=450)=26.52, \mathrm{p}<0.001$.

It is difficult to verify if such a gender gap is systematic and exists across all CPCs in the two provinces as CPCs are not obligated to publish their election plans or representatives' data online. However, data obtained on the proportion of women elected to 11 Hubei CPCs and 13 Hunan CPCs seems to lend some support for a cross-provincial gap. Among the 11 county units in Hubei that agreed to share data, an average of 25.7 per cent of elected representatives were women, while in Hunan the 13 CPCs reported an average of 32.9 per cent (see Table 4). The existence of this gap is especially compelling considering that historically Hunan and Hubei have had similar proportions of women in their CPCs. Based on Liu Zhi et al.'s research using data from the first four directly elected CPCs after 1979, the average proportion of women in all CPCs within Hubei was 23.2 per cent; the same figure in Hunan was slightly lower, at 21.9 per cent (see Figure 2). ${ }^{46}$

\section{Conclusion}

In an election that relies on the top-down selection of nominees rather than the voluntary and proactive running of candidates, affirmative action such as 
Table 4: Proportion of Female Representatives in Selected CPCs (2016)

\begin{tabular}{lcc}
\hline & Province & Proportion of Female Representatives \\
District A & Hunan & $40.00 \%$ \\
County A & Hunan & $37.00 \%$ \\
Yuhu district & Hunan & $26.70 \%$ \\
Wuling district & Hunan & $37.17 \%$ \\
Lusong district & Hunan & $31.14 \%$ \\
Hecheng district & Hunan & $33.82 \%$ \\
Louxing district & Hunan & $26.34 \%$ \\
Beihu district & Hunan & $33.84 \%$ \\
Yunxi district & Hunan & $24.20 \%$ \\
Yanfeng district & Hunan & $38.85 \%$ \\
Lengshuijiang county-level city & Hunan & $34.22 \%$ \\
Shuangfeng county & Hunan & $31.33 \%$ \\
Taoyuan county & Hunan & $33.12 \%$ \\
Mean & & $32.90 \%$ \\
District B & Hubei & $27.00 \%$ \\
County B & Hubei & $13.80 \%$ \\
Dongbao district & Hubei & $31.22 \%$ \\
Huangzhou district & Hubei & $29.03 \%$ \\
Duodao district & Hubei & $21.79 \%$ \\
Hongshan district & Hubei & $31.13 \%$ \\
Jiangxia district & Hubei & $28.24 \%$ \\
Xinzhou district & Hubei & $25.56 \%$ \\
Chibi county-level city & Hubei & $36.77 \%$ \\
Hefeng county & Hubei & $18.00 \%$ \\
Xuan'en county & Hubei & $20.50 \%$ \\
Mean & & $25.73 \%$ \\
Notes: & & \\
Data requested in person and via phone calls & with & \\
\end{tabular}

quota enforcement can be especially effective in increasing women's representation when socioeconomic factors are held constant. While the CCP's affirmative actions - for example, vetoing nominations, partnering Party nominees with less qualified voter nominees, and background checks - are primarily aimed at securing election victory for its preferred candidates, ${ }^{47}$ they have also proved to be crucial for implementing and fulfilling quotas. Despite the Hunan Provincial Communist Party's exhortations to include more grassroots representatives, local agents continued to nominate first hands until the organization department and CPC intervened. Without the Party's intervention during the nomination stage, the CPCs in Hunan would have just paid lip service to quotas to the effect that the quotas would have made no impact and would have been meaningless - as was the case with the CPCs in Hubei when they just nominated first hands under a different label.

While this study confirms the positive effects of top-down grassroots quota enforcement in CPCs, it also shows that gender quotas are still only loosely 
Figure 2: Average Proportion of Female Representatives in CPCs in Hunan and Hubei

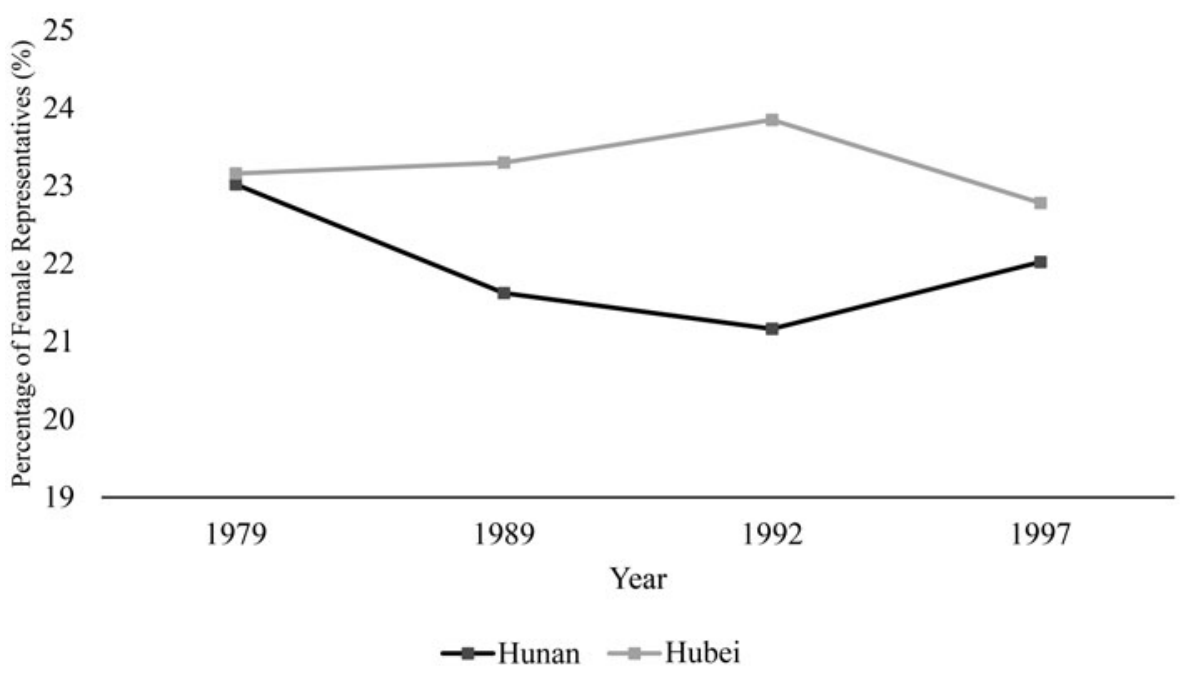

Source:

Liu, Zhi, et al. 2001.

observed and that their fulfilment is conditional upon the increase of representatives from other disadvantaged groups - in the cases here, grassroots representatives. This conclusion offers a number of takeaways for scholarship on Chinese politics and on gender and politics. First, the new opportunities for women in Hunan province were not deliberately or strategically designed as such; if anything, they are a side effect of Hunan's affirmative actions to incorporate more grassroots representatives. Since this initiative was launched in response to a recent scandal, it is still too early to gauge the longer-term prospects for women's representation in Hunan province. Second, while the study attempts to justify analysis of women's descriptive representation by illustrating research on substantive representation of the CPC representatives, owing to the limited scope of this paper it remains unclear whether the inclusion of women in Hunan province is able to translate into the substantive representation of women in the manner suggested by critical mass theory. ${ }^{48}$ Although past studies show that descriptive representation produces substantive representation in people's congresses, the factor of gender has never been explored. Particularly, when women are included under multiple quotas, which group do they represent? Since the women in this study are mostly included because they work in grassroots positions, would their inclusion then simultaneously reinforce the binaries of female/male and grassroots/officials in CPCs? How might the influx of 
grassroots female representatives influence the current legislative agendas dominated by powerful male representatives? This study leaves such questions for future research.

Third, in agreement with previous research, this study cautions against treating men's pathway to politics as a norm. ${ }^{49}$ In China, men and women follow different pathways to reach the CPCs. To enhance their chances of being elected, men usually choose to climb to the top of the nomenklatura system as the Party has traditionally nominated political and social elites into CPCs. Women, on the other hand, remain in the grassroots positions waiting to be called up by the Party since there is not much room left for women at the top. By incorporating such analysis on women's representation in different types of election/selection systems and identifying a wide array of hindrances and opportunities for women's inclusion in politics, this study further extends the literature on both Chinese politics and gender and politics.

Last, this article is limited in its sample size as it draws on the study of two rural counties and two urban districts in Hunan and Hubei. Whereas the findings indicate that the local practices that (dis)enable women's inclusion transcend the urban/rural county difference and are most likely to reflect a provincial-level difference, the lack of data on the proportion of women in the rest of the CPCs in the two provinces or the whole country obstructs a more general claim and a test of a causal relationship. This limitation points to several important avenues for future research on Chinese politics. The research design and findings could usefully be extended to consider a larger number of CPCs and to test the causal effect of grassroots quota enforcement in women's representation. Alternatively, as this study constitutes the first account of variation in subnational enforcement of gender quotas in people's congresses, research could further examine the variation on quota enforcement at different levels and across regions, and on how electoral authorities balance the descriptive representation of different groups during the enforcement of quotas.

\section{Acknowledgements}

I am thankful for the excellent suggestions of Alice Ba, Gretchen Bauer, Benjamin Bagozzi, Kara Ellerby, Mona Lena Krook, Wiebke Rabe, Kathrin Reed, Saloni Sharma and Lingxiao Yan. The paper also benefited from feedback on previous drafts presented at the American Political Science Association's Annual Meeting and the School of Political Science and Public Administration at Wuhan University. In addition, I am grateful for the research assistance provided by Liyou Li and Luping Wang, and fieldwork assistance from Xiamen University and Wuhan University. Funding from the American Association of University Women, the Carrie Chapman Catt Center for Women and Politics, and the University of Delaware is also gratefully acknowledged. 


\title{
Conflicts of interest
}

None.

\section{Biographical notes}

Xinhui JIANG is a postdoctoral researcher in the Institute of Chinese Studies at the Freie University of Berlin, Germany. She received her doctorate in political science and international relations from the University of Delaware. Her research interests lie in the field of gender and politics, legislative studies and Chinese politics.

\begin{abstract}
摘要：全世界各地的立法机构中均存在女性代表不足的问题，中国也不例 外。虽然中国共产党早在 1933 年就第一次设置了妇女参政的最低名额, 时至今日对中国性别配额和人大女性代表的相关研究一直非常有限。本文 通过探究县一级人大性别配额执行及女性代表数量在各地区的差异, 填补 了现有文献的空白。通过分析湖南和湖北省的四个虽然在社会经济等指标 上十分接近, 但在 2016 年的县人大选举结果中女性代表比例却大相径庭 的县级行政区，本文发现差异的来源是县人大对一线代表配额的设置及执 行。通过 2016 和 2017 年的田野调查, 作者发现虽然四个县均设置了百分 之三十的女性配额, 但只有湖南的两个县达到了这个要求。而究其原因, 是湖南省在 2013 年衡阳贿选案后开始大幅度提高一线代表的比例并严格 执行这一要求。与之相反，湖北依然提名了大量的“一把手”代表，而该群 体中本身就鲜有女性。
\end{abstract}

关键词; 女性代表; 中国选举; 性别配额; 性别与政治; 人民代表大会

\section{References}

Barnes, Tiffany D. 2016. Gendering Legislative Behavior: Institutional Constraints and Collaboration. New York: Cambridge University Press.

Beckwith, Karen, and Kimberly Cowell-Meyers. 2007. "Sheer numbers: critical representation thresholds and women's political representation." Perspectives on Politics 5(3), 553-565.

Carroll, Susan J., and Kira Sanbonmatsu. 2013. More Women Can Run: Gender and Pathways to the State Legislatures. Oxford: Oxford University Press.

Chang, Chun Chih, and Chien Min Chao. 2019. "Specialization without autonomy: an informational approach to the development of permanent committees in China's National People's Congress." Journal of Contemporary China 28(115), 64-80.

Childs, Sarah, and Mona Lena Krook. 2009. "Analysing women's substantive representation: from critical mass to critical actors." Government and Opposition 44(2), 125-145.

Franceschet, Susan, and Jennifer M. Piscopo. 2008. "Gender quotas and women's substantive representation: lessons from Argentina." Politics and Gender 4(03), 393-425.

Gerring, John. 2007. Case Study Research: Principles and Practices. Cambridge: Cambridge University Press.

Howell, Jude. 2006. "Women's political participation in China: in whose interests elections?" Journal of Contemporary China 15(49), 603-619. 
Huang, Dongya, and Quanling He. 2018. "Striking a balance between contradictory roles: the overlapping role perceptions of the deputies in China's local people's congresses." Modern China 44(1), 103-134.

Hunan Provincial Bureau of Statistics. 2016. Hunan funü fazhan guihua (2011-2015) zhongqi jiance pinggu baogao (Monitoring Report of Hunan Women's Development Program (2011-2015)). Changsha: Hunan sheng tongjiju.

Jacka, Tamara, and Sally Sargeson. 2015. "Representing women in Chinese village self-government: a new perspective on gender, representation, and democracy." Critical Asian Studies 47(4), 477-494.

Kenny, Meryl. 2013. Gender and Political Recruitment: Theorizing Institutional Change. London: Palgrave Macmillan.

Krook, Mona, and Fiona Mackay (eds.). 2011. Gender, Politics and Institutions: Towards a Feminist Institutionalism. London: Palgrave Macmillan.

Li, Yuejun. 2014. "Lixing xuanze zhidu zhuyi shijiao xia de Hengyang huixuan sheng renda daibiao an" (The Hengyang vote-buying case through the lens of rational choice institutionalism). Renda yanjiu, 5 June, http://www.rdyj.com.cn/Home/Books/detail/id/331.html. Accessed 2 May 2021.

Liu, Shunni, and Yongpo Ma. 2016. "Nongcun funü canyu nongcun shiwu minzhu guanli de xianzhuang ji sikao" (The status and reflections of rural women's participation in public affairs and democratic governance). Chutian zhuren 5, http://www.ctzrzz.com/a/index/1728.html. Accessed 27 April 2020.

Liu, Tianhong. 2017. "Zhong wai jiaoshi zhiye xingbie chaju duibi ji yingdui celüe" (Comparison of the gender proportions of teachers in domestic and international society and coping strategies). China Women's News, 5 September.

Liu, Zhi, Weimin Shi, Xiaodong Zhou and Yunhao Wu. 2001. Shuju xuanju (Election Data). Beijing: Shehui kexue chubanshe.

Luo, Ling. 2013. "She'an jin'e guoyi 500 duo ming renda daibiao shouhui" (Over 500 People's Congress representatives involved in a bribery case of more than 100 million yuan). BBC News, 28 December, https://www.bbc.com/zhongwen/simp/china/2013/12/131228_hunan_lawmakers_ resign. Accessed 2 May 2021.

Manion, Melanie. 2008. "When Communist Party candidates can lose, who wins? Assessing the role of local people's congresses in the selection of leaders in China." The China Quarterly 195, 607-630.

Manion, Melanie. 2014. "Authoritarian parochialism: local congressional representation in China." The China Quarterly 218, 311-338.

Manion, Melanie. 2015. Information for Autocrats: Representation in Chinese Local Congresses. New York: Cambridge University Press.

Norris, Pippa, and Joni Lovenduski. 1995. Political Recruitment: Gender, Race and Class in the British Parliament. Cambridge: Cambridge University Press.

O'Brien, Kevin J. 1990. Reform without Liberalization: China's National People's Congress and the Politics of Institutional Change. Cambridge: Cambridge University Press.

O'Brien, Kevin J. 1994. "Agents and remonstrators: role accumulation by Chinese people's congress deputies." The China Quarterly 138, 359-380.

Paxton, Pamela, and Sheri Kunovich. 2003. "Political women's representation: the importance of ideology." Social Forces 82(1), 87-113.

Potter, Pitman B. 1999. "The Chinese legal system: continuing commitment to the primacy of state power." The China Quarterly 119, 673-683.

Sargeson, Sally, and Tamara Jacka. 2017. "Improving women's substantive representation in community government: evidence from Chinese villages." Development and Change 49(5), 1166-94.

Seawright, Jason, and John Gerring. 2008. "Case selection techniques in case study research: a menu of qualitative and quantitative options." Political Research Quarterly 61(2), 294-308.

Shi, Weimin, and Jingxuan Lei. 1999. Zhijie xuanju: zhidu yu guocheng (Direct Election: Institutions and Processes). Beijing: Shehui kexue chubanshe. 
Sintomer, Yves, and Yunyun Zhou. 2019. "'Representation' and dàibiăo: a comparative study of the notions of political representation in France and China." Journal of Chinese Governance 4(4), 362-389.

Su, Fubing. 2006. "Gender inequality in Chinese politics: an empirical analysis of provincial elites." Politics and Gender 2, 143-163.

Sun, Long. 2011. Gongmin canyu: Beijing chengshi jumin taidu yu xingwei shizheng yanjiu (Public Participation: Empirical Research on the Public Attitude and Behaviour of Beijing Citizens). Beijing: Shehui kexue chubanshe.

Tan, Chang. 2016. "Mingji xiqu Hengyang pohuai xuanju anli shengke jiaoxun - Hunan congyan tuijin xianxiang renda xuanju huanjie guancha" (Remember and learn from the Hengyang votebuying case - observation of Hunan's promotion of a strict county and township people's congress election). Xinhua net, 27 November, http://www.xinhuanet.com//politics/2016-11/27/c_1119998033. htm. Accessed 27 April 2020.

Truex, Rory. 2016. Making Autocracy Work: Representation and Responsiveness in Modern China. New York: Cambridge University Press.

Wang, Qi. 2015. "In tailwind, in headwind: gender quotas in China." Indian Journal of Gender Studies 22(3), 387-407.

Wang, Shu. 2016. "Zhejian shi Xi Jinping san dian ming liufawen Hunan fanxing sannian hai budaowei" (Three name-callings and six questionings by Xi Jinping: what Hunan did is still not enough after three years). Xinjingbao, 26 September, http://news.sina.com.cn/c/nd/2016-06-10/ doc-ifxszfak3469158.shtml. Accessed 2 May 2021.

Wang, Xiong. 2017. "Zhizhengdang timing renda daibiao houxuanren zhidu jiqi yingxiang" (Research on the CCP nomination system for deputy candidates and its influence on the people's congress). Guangzhou daxue xuebao 16(2), 44-50.

Wang, Zhengxu, and Weina Dai. 2013. "Women's participation in rural China's self-governance: institutional, socioeconomic, and cultural factors in a Jiangsu county." Governance 26(1), 91-118.

Wang, Zhongyuan. 2017. "Playing by the rules: how local authorities engineer victory in direct congressional elections in China.” Journal of Contemporary China 26(108), 870-885.

Zhang, Yongying. 2012. "Funü zai renda zhong de canyu zhuangkuang ji yingxiang yinsu fenxi" (An analysis of the explanatory factor of women's participation in the congress). In Changxian Zhou (ed.), Funü canzheng: xin Zhongguo liushi nian de zhidu yanjin (Women's Political Participation: Sixty Years of Institutional Evolvement since the Establishment of the PRC). Beijing: Shehui kexue chubanshe, 139-149. 